\title{
KEPASTIAN PERLINDUNGAN HUKUM KESENIAN TRADISIONAL SEBAGAI EKSPRESI BUDAYA TRADISIONAL DALAM MENUNJANG KEPARIWISATAAN INDONESIA
}

\author{
Liza Marina ${ }^{1}$, Dessy Sunarsi ${ }^{2}$ \\ Fakultas Hukum, Universitas Sahid \\ Jl. Soepomo No 84, Jakarta Selatan \\ Email Korespondensi: lizausahid@gmail.com
}

\begin{abstract}
ABSTRAK
Perlindungan hukum merupakan suatu hal yang melindungi subyek-subyek hukum melalui peraturan perundang-undangan yang berlaku dan dipaksakan pelaksanaannya dengan suatu sanksi. Salah satu sifat dan sekaligus merupakan tujuan dari hukum adalah memberikan perlindungan (pengayoman) kepada masyarakat. Oleh karena itu, perlindungan hukum terhadap masyarakat tersebut harus diwujudkan dalam bentuk adanya kepastian hukum. Indonesia sebagai Negara kepulauan, memiliki keanekaragaman seni dan budaya yang sangat kaya. Hal itu sejalan dengan keanekaragaman etnik, suku bangsa dan agama yang secara keseluruhan merupakan potensi nasional yang perlu dilindungi. Kekayaan kesenian tradisional merupakan salah satu sumber dari karya intelektual yang dapat dan perlu dilindungi oleh undang-undang. Saat ini belum ada kepastian hukum terhadap perlindungan Ekspresi Budaya Tradisional Indonesia, mengingat regulasi masih memasukkan dalam Undang-Undang Hak Cipta. Perlu diatur secara tersendiri regulasi Ekspresi Budaya Tradisional secara khusus yang diikuti dengan Peraturan Pemerintahnya beserta sanksi yang tegas atas pelanggarannya.
\end{abstract}

Kata Kunci: Kepastian hukum, Perlindungan hukum, Kesenian tradisional, Ekspresi budaya tradisional.

\begin{abstract}
Legal protection is a matter that protects legal subjects through applicable laws and regulations and is forced to implement it with a sanction. One of the characteristics and at the same time is the purpose of the law is to provide protection (protection) to the community. Therefore, legal protection for these communities must be realized in the form of legal certainty. Indonesia as an archipelago, has a very rich diversity of arts and cultures. This is in line with the diversity of ethnicity, ethnicity and religion as a whole is a national potential that needs to be protected. The wealth of traditional arts is one source of intellectual work that can and needs to be protected by law. At present there is no legal certainty regarding the protection of Indonesian Traditional Culture Expressions, considering that regulations still include in the Copyright Act. It is necessary to regulate the regulation of Traditional Culture Expressions in particular which is followed by Government Regulations along with strict sanctions for violations.
\end{abstract}

Keyword: Law certitude, Legal protection, Traditional arts, Traditional culture expressions. 


\section{PENDAHULUAN}

Indonesia merupakan negara yang sangat banyak memiliki potensi kepariwisataan yang belum ditumbuhkan dengan sepenuhnya. Pariwisata sebagai salah satu penghasil devisa negara terbesar, memerlukan berbagai upaya untuk dapat lebih memaksimalkan peranan dan kontribusinya. Proses pengembangan berbagai potensi tesebut harus mengacu kepada pada daya saing yang berskala internasional, sehingga dalam pelaksnaannya diperlukan perangkat pengaturan lalu lintas hukum yang jelas. Salah satu atraksi pariwisata Indonesia adalah keanekaragaman seni budaya, yang membuat wisatawan mancanegara kagum disamping keindahan wisata alamnya serta cagar budayanya. Indonesia sebagai Negara kepulauan, memiliki keanekaragaman seni dan budaya yang sangat kaya. Hal itu sejalan dengan keanekaragaman etnik, suku bangsa dan agama yang secara keseluruhan merupakan potensi nasional yang perlu dilindungi. Kekayaan seni dan budaya tersebut merupakan salah satu sumber dari karya intelektual yang dapat dan perlu dilindungi oleh undang-undang. Kekayaan itu tidak semata-mata untuk seni dan budaya itu sendiri, tetapi dapat dimanfaatkan untuk meningkatkan kemampuan di bidang perdagangan dan industri yang melibatkan para penciptanya. Dengan demikian, kekayaan seni dan budaya yang dilindungi dapat meningkatkan kesejahteraan tidak hanya bagi para penciptanya saja, tetapi juga bagi bangsa dan negara.

Negara memajukan Kebudayaan Nasional Indonesia di tengah peradaban dunia dan menjadikan Kebudayaan sebagai investasi untuk membangun masa depan dan peradaban bangsa demi terwujudnya tujuan nasional sebagaimana diamanatkan oleh Undang-Undang Dasar Negara Republik Indonesia Tahun 1945; Keberagaman Kebudayaan daerah merupakan kekayaan dan identitas bangsa yang sangat diperlukan untuk memajukan Kebudayaan Nasional Indonesia di tengah dinamika perkembangan dunia; Untuk memajukan Kebudayaan Nasional Indonesia, diperlukan langkah strategis berupa upaya Pemajuan Kebudayaan melalui Pelindungan, Pengembangan, Pemanfaatan, dan Pembinaan guna mewujudkan masyarakat Indonesia yang berdaulat secara politik, berdikari secara ekonomi, dan berkepribadian dalam Kebudayaan.

Kebudayaan di Indonesia termasuk di dalamnya seni budaya, saat ini mulai menjadi perhatian khusus pemerintah untuk "dijual" ke pasar budaya internasional. Namun dalam perkembangan dan keberadaanya, kesenian tradisional lemah dari segi perlindungan. Misalnya saja, perlindungan atas hasil karya seniman tradisinya, perlindungan atas buah pemikiran intelektualnya berupa syair, lagu, musik, dongeng, seni tari tradisional dan lain sebagainya masih belum dibentuk perangkat hukumnya secara khusus. Masyarakat adat memahami pengetahuan tradisional dan ekspresi budaya tradisional sebagai warisan budaya yang dimiliki secara komunal (dimilik bersama). Sehingga muncul anggap bahwa pengetahuan tradisional dan ekspresi budaya tradisional menjadi sesuatu yang terbuka dan publik domein. Konflik kepentingan antara negara maju dengan negara berkembang mengenai pengetahuan tradisional dan ekspresi budaya tradisional harus dimasukan dalam perjanjian TRIPs. Negara maju lebih menginginkan bahwa pengetahuan tradisional dianggap sebagai public domein sehingga dapat diakses, hal ini sangat merugikan negara-negara berkembang. Sedang negara berkembang menganggap bahwa rezim HKI yang ada belum mampu melindungi kepentingan negara berkembang atas pengetahuan tradisional dan ekspresi budaya tradisional. Pengetahuan tradisonal merupakan tata nilai dalam kehidupan masyarakat adat antara lain dapat berupa tanaman obat dan pengobatan, seni ukir, seni tenun pemuliaan tanaman dan budaya 
masyarakat adat. Perlahan-lahan pengetahuan tradisional dan ekspresi budaya tradisional itu akan hilang sejalan dengan tergerusnya budaya tradisional dengan kemajuan zaman dan terpinggirkannya masyarakat adat. Hal ini karena kurangnya kesadaran mengenai pentingnya aset karya intelektual, tidak terdokumentasi nya pengetahuan adat tersebut dengan baik. Di sisi lain, pengetahuan tradisional dan ekspresi budaya tradisional adalah persoalan perlindungan hukum.

Kepemilikan Hak Kekayaan Intelektual terbagi menjadi dua bagian, yaitu bersifat personal dan komunal (Hawin dan Budi Agus Riswandi: Gajah Mada University Press, 2017). Budaya masuk dalam kategori komunal, yang artinya kekayaan yang dimiliki bersama-sama. Ini berarti, sangat sulit mendaftarkan kebudayaan bersifat HKI komunal. Karena hak paten itu hanya digunakan yang sifatnya penemuan, merek, dan desain industri. Kalaupun ingin didaftarkan, nantinya masuk ke dalam HKI kategori pribadi, yang berarti tergolong hak cipta. Hak cipta memiliki batas masa waktu yang bisa habis. Jika seorang menciptakan suatu penemuan, maka hak ciptanya akan terpakai selama dia hidup. Namun setelah meninggal dunia, hak cipta akan habis 70 tahun sejak sang pencipta wafat.

Ekspresi budaya tradisional merupakan masalah hukum baru yang berkembang baik di tingkat nasional maupun internasional. Pengetahuan tradisional dan ekspresi budaya tradisional sebagai kekayaan intelektual baru dalam waktu satu dekade terakhir muncul menjadi masalah hukum disebabkan belum ada instrumen hukum nasional maupun internasional memberikan perlindungan hukum secara optimal terhadap pengetahuan tradisional yang saat ini banyak dimanfaatkan oleh pihakpihak yang tidak bertanggung jawab. Hal ini disebabkan kurangnya perlindungan yang diberikan oleh negara terhadap pengetahuan tradisional dan ekspresi budaya tradisional yang dimanfaatkan oleh pihak-pihak yang tidak bertanggung jawab. Tanpa disadari banyak produk sumber daya hayati dan karya intelektual lokal masyarakat Indonesia itu telah disalahgunakan, bahkan telah di daftarkan hak intelektualnya oleh pihak asing. Salah satu pihak asing yang telah banyak mempergunakan tanpa izinnkarya seni tradisional Indonesia, adalah Malaysia. Contohnya seperti alat musik angklung reog ponorogo dan Lagu Rasa Sayange. Lagu Rasa Sayange yang diklaim oleh pemerintah Malaysia sebagai lagu milik bangsanya di pergunakan sebagai jingle iklan pariwisata negara Malaysia dan dikumandangkan pada peringatan hari ulang tahun Malaysia yang ke 50.

Pasal 39 Undang-Undang No. 28 Tahun 2014 menyatakan bahwa hak cipta atas ekspresi budaya tradisional dipegang oleh Negara. Negara wajib menginventarisasi, menjaga dan memelihara ekspresi budaya tradisional. Penggunaan ekspresi budaya tradisional harus memperhatikan nilai-nilai yang hidup dalam masyarakat pengembannya. Dalam Pasal 39 ayat (4) menyatakan bahwa ketentuan lebih lanjut mengenai Hak Cipta yang dipegang oleh Negara atas ekspresi budaya tradisional diatur dengan Peraturan Pemerintah, akan tetapi hak cipta terkait ekspresi budaya tradisional yang depagang oleh negara belum ada peratran pemerintahnya. Berdasarkan perumusan ketentuan Pasal 39 tersebut, tidak mencakup perlindungan terhadap hak cipta pengetahuan tradisional masyarakat adat. Artinya, kedudukan pengetahuan tradisional masyarakat adat rentan untuk dieksplotasi oleh pihak lain. Padahal perlindungan terhadap pengetahuan tradisional penting karena merupakan sumber pengetahuan yang berhubungan dengan kehidupan manusia yang dapat dikomersialkan.

Ekspresi Kebudayaan Tradisional sebagai bagian dari Hak Kekayaan Intelektual di 
negara-negara berkembang seperti Indonesia belum mendapatkan perlindungan, sebagaimana kekayaan intelektual di negara maju. Negara-negara maju berupaya sedemikian rupa untuk melindungi kekayaan intelektual mereka dari penyalahgunaan, dengan jalan menekan negara-negara di dunia ketiga, untuk melindungi hak kekayaan intelektual mereka. Keengganan negara maju untuk mengakui pengetahuan dan ekspresi kebudayaan negara- negara berkembang, disebabkan karena mereka tidak ingin kehilangan akses mengambil pengetahuan dan ekspresi kebudayaan tradisonal masyarakat lokal, yang telah terbukti sangat menguntungkan bagi mereka, baik secara ekonomis

\section{PERMASALAHAN}

Permasalahan yang dibahas dalam tulisan ini adalah bagaimana kepastian perlindungan hukum kesenian tradisional sebagai bagian dari Ekspresi budaya tradisional dalam menunjang kepariwisataan Indonesia.

\section{PEMBAHASAN}

Indonesia sebagai negara yang kaya akan kebudayaan, terutama kesenian tradisional, harus melindungi pengetahuan tradisional dan ekspresi budaya tradisional yang ada di dalam wilayah Negara Kesatuan Republik Indonesia dari ancaman pengakuan oleh negara lain atau pemanfaatan oleh warga negara lain. Bagi masyarakat Indonesia pada umumnya, pengetahuan tradisional dan ekspresi kebudayaan adalah bagian integral dari kehidupan sosial masyarakat yang bersangkutan. Pengetahuan tradisional (PT) dan ekspresi budaya tradisional (EBT) merupakan aset negara yang sangat potensial bagi kemakmuran bangsa karena memiliki nilai ekonomi yang tinggi, tetapi kepemilikannya banyak diakui (diklaim) oleh pihak asing tanpa adanya benefit sharing, sehingga terjadi konflik kepentingan antara negara maju dan negara berkembang seperti Indonesia. Kelemahan Indonesia dalam mengembangkan sistem perlindungannya belum adanya sistem perlindungan yang tepat dan memadai serta terbatasnya data, dokumentasi dan informasi tentang Pengetahuan Tradisional dan Ekspresi Budaya Tradisional.

Pengetahuan Tradisional adalah karya intelektual di bidang pengetahuan dan teknologi tradisional yang dihasilkan, dikembangkan, dan dipelihara oleh komunitas atau masyarakat tertentu. Sedangkan pengertian Ekspresi Budaya Tradisional adalah karya intelektual dalam bidang seni, termasuk ekspresi sastra yang mengandung unsur karakteristik warisan tradisional yang dihasilkan, dikembangkan, dan dipelihara oleh komunitas atau masyarakat tertentu (RUU PTEBT). Ekspresi Budaya Tradisional berakar dalam tiga kata, tradisi, budaya dan ekspresi. Untuk "ekspresi", itu berarti untuk mengungkapkan atau tujuan yang jelas, ide atau perasaan. Budaya dalam bahasa Inggris sesuai dengan "budaya" di Indonesia. Hal ini berakar pada bahasa Sansekerta "budhayah" yang berarti pikiran atau intelektual. Secara umum, budaya dapat didefinisikan sebagai sesuatu yang dihasilkan oleh pikiran manusia dan intelek untuk mengembangkan dan mempertahankan hidup mereka di lingkungan mereka.ekspresi budaya tradisional adalah bagian dari kehidupan budaya masyarakat sebagai pemilik. Ekspresi budaya tradisional sudah mengandung beberapa nilai seperti ekonomi, spiritualitas dan komunalitas. Ekspresi budaya tradisional dapat mewakili identitas masyarakat adat di daerah tertentu.

Ketika tugas menginventarisasi data kepemilikan kesenian tradisional yang sudah turun termurun dengan memperhatikan nilai-nilai budaya masyarkatnya diperlukan 
pengetahuan tradisional. Pengetahuan tradisional mengacu pada pengetahuan, inovasi dan praktek masyarakat adat dan lokal di dunia yang dikembangkan dari pengalaman mereka di abad dan menurut, pengetahuan tradisional langsung budaya dan lingkungan ditransfer secara lisan dari generasi ke generasi. ini adalah kolektif yang dimiliki dan dikelola dalam beberapa bentuk seperti cerita rakyat, lagu- lagu rakyat, peribahasa, nilainilai budaya, iman, ritual, hukum masyarakat, bahasa lokal dan keturunan hewan. Perlindungan hukum terhadap ekspresi budaya tradisional sangat dibutuhkan oleh negara- negara berkembang, karena perlindungan dianggap sebagai tindakan yang diambil untuk menjamin kelangsungan hidup warisan budaya tak benda dan kreativitas komunal.

Ada dua hal yang dapat dilakukan guna memberikan perlindungan hukum atas pengetahuan tradisional:

1. Untuk jangka pendek perlindungan dengan system inventarisasi atau dokumentasi pengetahuan tradisional yang ada, hal ini tidak saja memberikan fungsi informatif tetapi juga dapat digunakan sebagai fungsi pembuktian hukum. Pendokumentasian dapat dilakukan dengan cara foto, tulisan atau catatan khusus yang dibuat oleh pemerintah. Inventarisasi atau dokumentasi atas kebudayaan tradisional merupakan kegiatan pendataan atas suatu kebudayaan tradisional di suatu wilayah, yang dengan adanya data tersebut kebudayaan tradisional suatu masyarakat dapat terinventarisir. Inventarisasi sendiri dapat dilakukan dalam berbagai bentuk, di antaranya adalah berupa penerbitan inventarisasi pengetahuan yang tertulis (berbentuk buku), atau juga dapat berupa inventarisasi dengan menggunakan database dikomputer.

2. Untuk jangka menengah dan panjang dengan mengeluarkan peraturan yang secara khusus melindungi pengetahuan tradisional. Salah satu cara untuk memperjuangkan kepentingan nasional di tingkat internasional adalah dengan menciptakan peraturan perundang- undangan nasional yang mengatur pula masalah-masalah yang bersifat internasional.

Perlindungan hukum merupakan suatu hal yang melindungi subyek-subyek hukum melalui peraturan perundang-undangan yang berlaku dan dipaksakan pelaksanaannya dengan suatu sanksi. Salah satu sifat dan sekaligus merupakan tujuan dari hukum adalah memberikan perlindungan (pengayoman) kepada masyarakat. Oleh karena itu, perlindungan hukum terhadap masyarakat tersebut harus diwujudkan dalam bentuk adanya kepastian hukum. Berkaitan dengan penegakan hukum hak cipta tersebut, bahwa masalah pokok dalam penegakan hukum hak cipta di Indonesia adalah Pemerintah Indonesia belum menunjukkan kemauan yang kuat untuk menegakkan perlindungan hak cipta di Indonesia, kemudian perundang-undangan hak cipta yang belum kompherensif. Di samping itu pada umumnya, pengetahuan masyarakat masih sangat kurang tentang hak cipta khususnya dan hak milik kekayaan pada umumnya termasuk hukum yang mengaturnya. Bahkan, kalangan masyarakat yang terkait langsung dengan ciptaan yang dilindungi itu pun, seperti pencipta dan pemegang hak terkait banyak yang kurang mengetahui hak cipta sangat kurang, pada umumnya masyarakat tidak menyadari arti pentingnya perlindungan hak cipta bagi pengembangan kebudayaan, peningkatan kreativitas masyarakat dan pembangunan ekonomi.

Perlindungan Ekspresi Budaya Tradisional menjadi sangat penting mengingat bahwa kepemilikan nya secara komunal dalam upaya melestarikan hak bangsa dan negara ditengah persaingan global. EBT ini mempunyai potensi nilai ekonomis atas 
karya budaya masyarakat yang bersangkutan, sehingga dalam kapasitas industri pariwisata yang dapat dipertunjukkan kepada wisman dan wisnus dapat mensejahterakan masyarakat itu sendiri dalam me3ningkatkan Pendapatan Asli Daerahnya.

Upaya perlindungan kesenian tradisional atau ekspresi budaya tradisional juga bisa dilakukan dengan cara mempublikasikan budaya itu seluas-luasnya. Pemerintah Indonesia melalui Undang-Undang No. 5 Tahun 2017 telah memberikan perlindungan terhadap ekspresi budaya tradisional yang dilakukan dengan cara membuat data base kekayaan tersendiri. Nanti disiarkan ke internet agar semua orang tahu (kesenian tradisional itu) asalnya Indonesia, siapa maestronya, siapa ahlinya, siapa guru yang bisa didatangi kalau mau belajar, itu cara melindunginya. Dalam Pasal 16 ayat (4) UndangUndang No. 5 Tahun 2017 diatur tentang Pemajuan Kebudayaan, Inventarisasi Objek Pemajuan Kebudayaan terdiri atas tahapan: 1) pencatatan dan pendokumentasian; 2) penetapan; 3) pemutakhiran data. Pengamanan Objek. Namun dalam praktik masih sebagian besar belum melakukan pendataan tersebut dalam mengimplementasikan UU Hak Cipta jo. UU Nomor 5 Tahun 2017. Dalam mengiventarisir terkait karya cipta kesenian tradisional yang tidak diketahui penciptanya. Disinilah peranan Pemerintah Daerah untuk dapat menginisiasi dan memberikan perlindungan aktif. Yang tahu tentang masyarakat dan hasil karyanya adalah Pemdanya. Disamping itu juga perlu didukung oleh kesadaran masyarakat untuk memprotek karya kesenian tradisional miliknya. Karakterisk hak cipta adalah keaslian dalam membuat karya cipta. Karya tersebut harus dihasilkan oleh orang yang mengakuinya sebagai ciptaannya. Karya tersebut tidak boleh disalin atau direproduksi dari karya lain.

Pencatatan ini bersifat sukarela. Permasalahan dilapangan dalam menginventarisir keasliannya, ketika menentukan siapa pemiliknya, untuk suku yang sama tetapi dibatasi oleh batas negara contoh suku Dayak Iban terdapat di tiga tempat yaitu Indonesia dan Malaysia dan Brunai. Kesenian Tradisionalnya tentua ada kemiripan bahkan juga namanya sama. Dalam hal ini Pemerintah Daerah Kalimantan Barat harus aktif dalam memprotek dengan seringnya dipentaskan dalam setiap kesempatan pertunjukan kesenian kpd wisatawan. Pasal 22 ayat 4 UU Nomor 5 tahun 2017 menyatakan Pemajuan Kebudayaan dilakukan dengan cara: 1) memutakhirkan data dalam Sistem Pendataan; 2) Kebudayaan Terpadu secara terus-menerus; 3) mewariskan Objek. Pemajuan Kebudayaan kepada generasi berikutnya; 4) memperjuangkan Objek Pemajuan Kebudayaan sebagai warisan budaya dunia.

Salah satu contoh yang dilakukan oleh Pemerintah Jawa Barat adalah dilakukannya inventarisasi usulan karya atau produk unggulan dari 27 kabupaten atau kota di Jawa Barat, yang telah melalui serangkaian verifikasi dan penyeleksian oleh tim penyusun, telah di peroleh hasil beberapa karya atau produk dari 19 kabupaten atau kota yang telah memenuhi syarat dan kriteria yang akan di ajukan melalui hak kekayaan intelektual. Beberapa karya atau produk dari 19 kabupaten atau kota ini sebagai berikut:

Tabel 1. Produk Unggulan yang diusulkan untuk mendapat hak cipta Prov Jawa Barat

\begin{tabular}{|l|l|l|l|}
\hline No. & Kabupaten/Kota & Karya/Produk Budaya & Keterangan \\
\hline 1 & Kota Depok & Tari Neang Sora & \\
\hline 2 & Kab. Cianjur & Teknik Pembelajaran Mamaos & \\
\hline
\end{tabular}




\begin{tabular}{|l|l|l|l|}
\hline & & Cianjuran & \\
\hline 3 & Kab. Sukabumi & Tari Dog-Dog Lojor & \\
\hline 4 & Kota Sukabumi & Tari Pakujajar & \\
\hline 5 & Kab. Subang & $\begin{array}{l}\text { Album Musik Kawih Murangkalih } \\
\text { Balik Ka Sawah }\end{array}$ & \\
\hline 6 & Kab. Karawang & Kendang Karawang Abah Wita & \\
\hline 7 & Kab.Bekasi & Tari Jejingkrakan & \\
\hline 8 & Kota Cirebon & Tari Jembar Agung & \\
\hline 9 & 9 Kab.Cirebon & Wawang Babad & \\
\hline 10 & Kab. Majalengka & Tari Kedempling & \\
\hline 12 & Kab. Sumedang & Kab. Sumedang Reak Kreasi & \\
\hline 13 & Kota Banjar & Tari Deleng & \\
\hline 14 & Kota Bandung & Seni Jurig Sarengseng & \\
\hline 15 & Kab. Bandung & Angklung Ragam Laras & \\
\hline 16 & Kab. Bandung Barat & Tari Dayang Sumbi & \\
\hline 17 & Kota Cimahi & Bangbarongan Durciang & \\
\hline 18 & Kab. Tasikmalaya & Angklung Landung & \\
\hline 19 & Kota Tasikmalaya & Angklung Badud & \\
\hline
\end{tabular}

Sumber : Dinda Aulia Amini, 151000189 (2019) Perlindungan Hukum Terhadap Ekspresi Budaya Tradisional Untuk Mewujudkan Perkembangan Ekonomi Kreatif Di Tinjau Dari UndangUndang Nomor 28 Tahun 2014 Tentang Hak Cipta Jo Undang-Undang Nomor 5 Tahun 2017 Tentang Pemajuan Kebudayaan. Skripsi(S1) thesis, Fakultas Hukum Universitas Pasundan

Pemeliharaan Objek Pemajuan Kebudayaan dilakukan dengan cara: 1) menjaga nilai keluhuran dan kearifan Objek; 2) Pemajuan Kebudayaan; 3) menggunakan Objek Pemajuan Kebudayaan dalam kehidupan sehari-hari; 4) menjaga keanekaragarnan Objek Pemajuan Kebudayaan; 5) menghidupkan dan menjaga ekosistem Kebudayaan untuk setiap Objek Pemajuan Kebudayaan; dan 6) mewariskan Objek Pemajuan Kebudayaan kepada generasi berikutnya. Penyelamatan Objek Pemajuan Kebudayaan dilakukan dengan cara: 1) revitalisasi; 2) repatriasi; dan/ atau 3). Restorasi (Pasal 26 ayat 3). Publikasi dilakukan untuk penyebaran informasi kepada publik baik di dalam negeri maupun di luar negeri dengan menggunakan berbagai bentuk media (Pasal 28 ayat 3). Pengembangan Objek Pemajuan Kebudayaan dilakukan dengan cara: 1) penyebarluasan; 2) pengkajian;dan 3) pengayaan keberagaman.(Pasal 30 ayat 3).

Perlindungan Ekspresi Budaya Tradisional (EBT) melalui hukum cipta merupakan salah bentuk perlindungan yang paling relevan dalam prinsip-prinsip hukum kekayaan intelektual. Pasal 38 Undang-Undang Hak Cipta menyatakan bahwa hak cipta atas ekspresi budaya tradisional dipegang oleh Negara. Negara wajib menginventarisasi, menjaga dan memelihara ekspresi budaya tradisional. Penggunaan ekspresi budaya tradisional harus memperhatikan nilai-nilai yang hidup dalam masyarakat pengembannya. Dalam Pasal 38 ayat (4) menyatakan bahwa ketentuan lebih lanjut mengenai Hak Cipta yang dipegang oleh Negara atas Ekspresi budaya tradisional diatur dengan Peraturan Pemerintah, akan tetapi hak cipta terkait ekspresi budaya tradisional yang dipegang oleh negara belum ada Peraturan Pemerintah sebagai peraturan pelaksanaanya nya. Hal ini pula menjadi hambatan dalam penerapan hukumnya. Sementara itu atas inisiaf Dewan Perwakilan Daerah, saat ini sedang dibahas mengenai pembentukan Rancangan Undang- Undang tentang Perlindungan dan Pemanfaatan 
Kekayaan Intelektual, Pengetahuan Tradisional, dan Ekspresi Budaya Tradisional. Namun sampai saat ini masih terus dalam pembahasan.

\section{KESIMPULAN DAN SARAN}

\section{Kesimpulan}

Saat ini belum ada kepastian hukum perlindungan terhadap kesenian Budaya tradisional sebagai bagian dari Ekspresi Budaya Tradisional Indonesia, mengingat regulasinya masih menyatu dalam UU Nomor 28 Tahun 2014 tentang Hak Cipta. Ada Perbedaan dalam hal kepemilikan bahwa hak Cipta umumnya dilimiki secara individual, sedangkan kepemilikan EBT adalah komunal. Kepemilikan komunal unik dapat dikomersialisasikan dan bernilai ekonomis. Pemda mempunyai peranan penting dalam mengadakan pendataan untuk mencatatkan Kesenian Tradisional masyarkatnya sebagai EBT ke DJKI Kementerian Hukum dan HAM. Pemda dala hal ini yang mengetahui dan memahami masyarakatnya dengan potensi EBT yang dimiliknya.

\section{Saran}

Pemerintah harus mendirong lahirnya regulasi tersendiri tentang pengaturan Ekspresi Budaya Tradisional secara khusus yang diikuti dengan Peraturan Pemerintahnya beserta sanksi yang tegas atas pelanggarannya, guna perlindungan hukum terhadap warisan budaya bangsa kesenian tradisional Indonesia.

\section{DAFTAR PUSTAKA}

Amini, D. A. (2019). Perlindungan Hukum Terhadap Ekspresi Budaya Tradisional Untuk Mewujudkan Perkembangan Ekonomi Kreatif Di Tinjau Dari Undang-Undang Nomor 28 Tahun 2014 Tentang Hak Cipta Jo Undang-Undang Nomor 5 Tahun 2017 Tentang Pemajuan Kebudayaan (Doctoral dissertation, Fakultas Hukum Universitas Pasundan).

Atsar, A. (2018). Perlindungan Hukum Terhadap Pengetahuan dan Ekspresi Budaya Tradisional untuk Meningkatkan Kesejahteraan Masyarakat ditinjau dari UndangUndang No. 5 Tahun 2017 Tentang Pemajuan Kebudayaan dan Undang-Undang No. 28 Tahun 2014 Tentang Hak Cipta. LAW REFORM, 13(2), 284-299.

Hadikusuma, H. (2003). Pengantar ilmu hukum adat Indonesia. Mandar Maju.

Hawin, M., \& Riswandi, B. A. (2017). Isu-isu penting hak kekayaan intelektual di Indonesia. Gadjah Mada University Press.

Lodra, I. N. (2012). Perlindungan Pengetahuan Tradisional dan Praktek HKI. Urna Jurnal Seni Rupa, 1(1).

Nomor, U. U. (28). tahun 2014 tentang Hak Cipta. Lembaran Negara Republik Indonesia Nomor, 266. 
Nomor, U. U. (5). Tahun 2017 Tentang Pemajuan Kebudayaan.

Penelitian, B., Hukum, P. H. K., \& HAM, R. (2013). Perlindungan Kekayaan Intelektual Atas Pengetahuan Tradisional dan Ekspresi Budaya Tradisional Masyarakat Adat. Alumni, Bandung.

Saidin, O. K. (2004). Aspek hukum hak kekayaan intelektual (Intellectual property rights).

Sardjono, A. (2010). Hak kekayaan intelektual dan pengetahuan tradisional. Alumni.

Sardjono, A. (2009). Membumikan HKI di Indonesia. Nuansa Aulia.

Ubbe, A. (2011). Laporan pengkajian hukum tentang mekanisme penanganan konflik sosial. Pusat Penelitian dan Pengembangan Sistem Hukum Nasional, Badan Pembinaan Hukum Nasional, Kementerian Hukum dan HAM RI. 